\title{
PENGARUH BAURAN PEMASARAN TERHADAP KEPUTUSAN KONSUMEN DALAM MEMBELI AIR MINUM KEMASAN YEH BULELENG (Studi Kasus di Kabupaten Buleleng)
}

\author{
K.E.S. Putra \\ Jurusan Manajemen, Universitas Pendidikan Ganesha, Singaraja \\ e-mail: kmendrawan.sp@gmail.com
}

\begin{abstract}
Abstrak
Sebagai perusahaan yang memproduksi air minum kemasan Yeh Buleleng, PT Tirta Mumbul Jaya Abadi berusaha mengimplementasikan bauran pemasaran untuk mempengaruhi keputusan konsumen dalam membeli air minum kemasan Yeh Buleleng. Namun melihat market share air minum kemasan Yeh Buleleng yang masih kalah dengan air minum kemasan Aqua menjadikan pertanyaan besar bagi manajemen PT Tirta Mumbul Jaya Abadi sampai sejauh mana pengaruh masing-masing bauran pemasaran tersebut terhadap keputusan konsumen dalam membeli air minum kemasan Yeh Buleleng. Penelitian ini bertujuan untuk mengetahui pengaruh bauran pemasaran terhadap keputusan konsumen dalam membeli air minum kemasan Yeh Buleleng. Teknik dalam penentuan anggota sampel menggunakan dua teknik secara berurutan yaitu: cluster sampling dan proportionate stratified random sampling. Hasil penelitian menunjukkan bahwa secara parsial bauran pemasaran yang terdiri dari produk, harga, promosi dan saluran distribusi berpengaruh positif dan signifikan terhadap keputusan konsumen dalam membeli air minum kemasan Yeh Buleleng. Secara simultan juga dapat diketahui bahwa bauran pemasaran berpengaruh positif dan signifikan secara simultan terhadap keputusan konsumen dalam membeli air minum kemasan Yeh Buleleng. Berdasarkan hasil analisis regresi berganda dapat diketahui bahwa variabel saluran distribusi lebih berpengaruh dominan terhadap keputusan konsumen dalam membeli air minum kemasan Yeh Buleleng.
\end{abstract}

Kata Kunci: Bauran Pemasaran, Keputusan Pembelian

\section{Abstract}

As a company that manufactures Yeh Buleleng bottled water, PT Tirta Mumbul Jaya Abadi is trying to implement a marketing mix to influence consumers' decisions to buy Yeh Buleleng bottled water. But seeing the market share of bottled water from Yeh Buleleng, which is still inferior to Aqua bottled water, makes a big question for the management of PT Tirta Mumbul Jaya Abadi to what extent the influence of each marketing mix on consumers' decisions in buying Yeh Buleleng bottled water. This study aims to determine the effect of the marketing mix on consumer decisions in buying Yeh Buleleng bottled water. The technique in determining sample members uses two techniques in sequence: cluster sampling and proportionate stratified random sampling. The results showed that partially the marketing mix consisting of products, prices, promotions and distribution channels had a positive and significant effect on consumers' decisions in buying Yeh Buleleng bottled water. Simultaneously it can also be seen that the marketing mix has a positive and significant effect simultaneously on consumers' decision to buy Yeh Buleleng bottled water. Based on the results of multiple regression analysis, it can be seen that the distribution channel variable is more dominantly influencing the consumer's decision to buy Yeh Buleleng bottled water.

Keywords: Marketing Mix, Consumers' Buying Decision

\section{Pendahuluan}

Keputusan konsumen dalam membeli suatu produk air minum higienis, tentunya tidak terlepas dari adanya pengaruh dari pelaku bisnis khususnya para pemasar terhadap perilaku konsumen itu sendiri. Pemasar harus menggunakan strategi pemasaran yang tepat agar dapat mempengaruhi perilaku konsumen dalam membeli suatu produk. Hal ini tentunya sangat berkaitan dengan adanya perubahan konsep dalam ilmu pemasaran, di mana filosofi pemasaran terdahulu yaitu "buat dan jual" yang berpusat pada produk bergeser ke filosofi "pahami dan tanggapi tentang kebutuhan konsumen". Memahami dan menanggapi kebutuhan konsumen agar menghasilkan suatu keputusan pembelian bukanlah suatu perkara yang mudah. Keputusan pembelian oleh konsumen muncul melalui proses yang 
sangat panjang. Bagaimana caranya produsen agar dapat mempengaruhi konsumennya merupakan hal yang memerlukan perencanaan dan pengawasan yang matang serta perlu dilakukan tindakan-tindakan kongkrit dan terprogram. Kotler dan Keller (2008:23) mengatakan bauran pemasaran harus dibuat untuk mempengaruhi saluran dagang dan juga keputusan pembelian konsumen akhir. Untuk keperluan tersebut, maka produsen dapat melakukan tindakan-tindakan yang memadukan empat macam hal yang lazim disebut dengan bauran pemasaran. Menurut Stanton dalam Dharmmesta dan Handoko (2008:124) mendefinisikan bauran pemasaran sebagai kombinasi dari empat variabel atau kegiatan inti dari sistem pemasaran perusahaan, yaitu produk, harga, promosi dan distribusi. Mowen dan Minor (2002:58) mengungkapkan penciptaan bauran pemasaran meliputi inisiatif dan koordinasi dari kegiatan yang berkaitan dengan pengembangan produk, promosinya, penetapan harga dan distribusinya. Kotler dan Amstrong (2004:56), menyatakan bauran pemasaran adalah seperangkat alat pemasaran taktis yang dikendalikan produk harga, promosi, dan saluran distribusi yang dipadukan oleh perusahaan untuk menghasilkan respon yang diinginkan dalam pasar sasaran. Assauri (2009:198), menegaskan bauran pemasaran terdiri atas himpunan variabel yang dapat dikendalikan dan digunakan oleh perusahaan untuk mempengaruhi tanggapan pembelian konsumen dalam pasara sasaranya.

Menurut Schiffman dan Kanuk (2007:16), pengambilan keputusan pembelian oleh konsumen dipandang sebagai suatu sistem yang terdiri atas input, proses dan output. Proses pengambilan keputusan terdiri atas tiga tahap proses yang dilakukan yakni tahap pengakuan adanya kebutuhan (konsumen merasakan adanya kebutuhan), usaha pencarian informasi sebelum membeli dan penilaian terhadap alternatif. Suryani (2008:17), menyatakan proses pengambilan keputusan pembelian tidak terlepas dari pengaruh pemasaran perusahaan melalui bauran pemasaran. Menurut McCarthy dalam Kotler dan Keller (2008:23), bauran pemasaran merupakan perangkat alat pemasaran perusahan dalam mencapai tujuan pemasarannya yang terdiri atas empat kelompok besar yaitu: produk (product), harga (price), promosi (promotion), dan tempat (place). Hal ini diperkuat oleh beberapa hasil penelitian yang dilakukan oleh para ahli tentang hubungan bauran pemasaran dengan keputusan pembelian. (Nunes dkk dalam Siringgoringo, 2004) menemukan bahwa konsumen kurang tertarik untuk membayar, atau mau membayar lebih rendah untuk produk dengan biaya variabel relatif rendah dan biaya tetap tinggi. Hasil studi Nunes ini menunjukkan pentingnya manajemen memperhatikan struktur biaya dalam penetapan harga, yang nantinya akan mempengaruhi keputusan pembelian konsumen. Hand dkk (1994) menemukan bahwa tingkat harga mempengaruhi perilaku konsumen dalam sikap penerimaan resiko pembelian. Hasil Hand menunjukan semakin tinggi level harga, maka resiko pembatalan pembelian oleh konsumen akan semakin tinggi pula.

Pendapat para ahli tentang bauran pemasaran diperkuat oleh beberapa hasil penelitian oleh peneliti tentang hubungan bauran pemasaran dengan keputusan pembelian. Faizah dan Rachmawati (2013) menemukan bahwa variabel bauran pemasaran dalam bentuk lokasi penjualan mempengaruhi keputusan konsumen untuk membeli air minum aqua di wilayah Bekasi. Foster (2016) menemukan variabel image merek dalam bauran pemasaran yang mempengaruhi konsumen dalam membeli air botol Amidis di Jakarta. Sedangkan Fauzan (2010) menemukan variabel kualitas produk yang mempengaruhi konsumen dalam membeli air minum beroksigen airox di Bogor.

Adanya pengaruh bauran pemasaran terhadap keputusan pembelian konsumen seperti ini ternyata dimanfaatkan oleh PT Tirta Mumbul Jaya Abadi. Sebagai salah satu perusahaan air minum hiegienis dalam kemasan yang belum lama berdiri, PT Tirta Mumbul Jaya Abadi mencoba memanfaatkan peluang bisnis dalam usaha air minum hiegienis dalam kemasan di Pulau Bali khususnya di Bali utara dengan merek Yeh Buleleng. PT Tirta Mumbul Jaya Abadi mengeluarkan beberapa jenis kemasan produk antara lain: kemasan galon 20 liter, kemasan botol $600 \mathrm{ml}$, kemasan botol $330 \mathrm{ml}$, dan kemasan gelas $250 \mathrm{ml}$ agar dapat memasuki dan bersaing dengan kompetitor lain dalam pasar air minum dalam kemasan di Kabupaten Buleleng. Melalui lima jenis kemasan produk tersebut, PT Tirta Mumbul Jaya Abadi pelan tapi pasti dapat merambah pasar air minum kemasan di Kabupaten Buleleng padahal terdapat banyak produk air minum kemasan yang telah lama 
dan memiliki brand (merek) terkenal yang ikut bersaing untuk mendapatkan pasar di Kabupeten Buleleng. Kondisi ini dapat dilihat pada market share air minum kemasan di Kabupaten Buleleng.
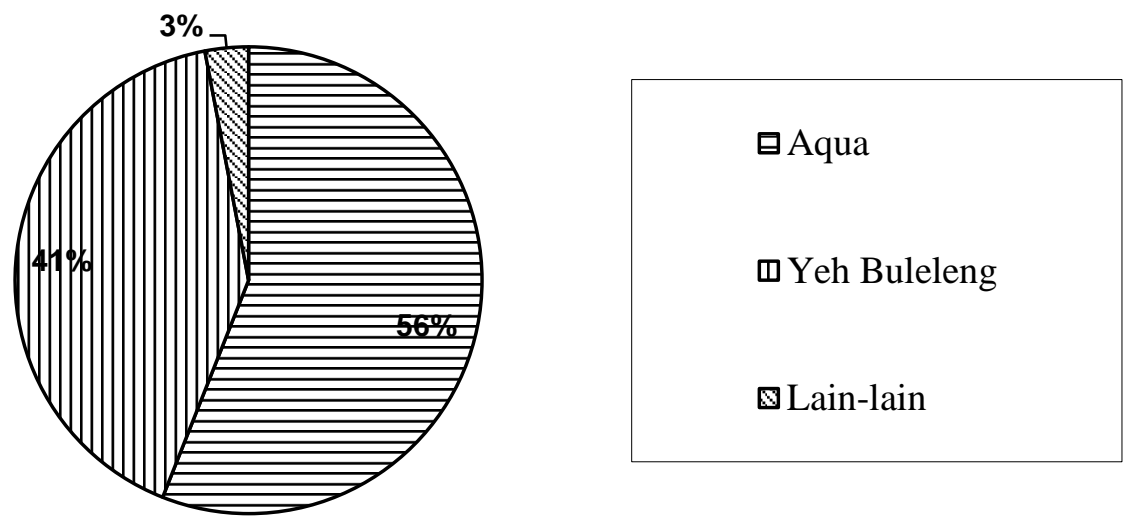

Gambar 1 Market Share Air Minum Kemasan di Kabupaten Buleleng

Berdasarkan Gambar 1, dapat diketahui bahwa Air minum kemasan Yeh Buleleng memperoleh pangsa pasar sebesar 41 persen, Air minum kemasan merek Aqua sebesar 56 persen, sedangkan air minum kemasan merek lainnya (Total, Vit, Club, Cheers dan $\mathrm{Ne}$ Bali) hanya menguasai tiga persen pangsa pasar di Kabupaten Buleleng. Hal ini mengindikasikan bahwa saingan utama air minum kemasan Yeh Buleleng di Kabupaten Buleleng adalah air minum kemasan merek Aqua.

Selama ini PT Tirta Mumbul Jaya Abadi telah berusaha menerapkan standarisasi kualitas produk. Hal ini dilakukan agar tercipta air minum kemasan yang memiliki daya tahan yang lama, higienis, warna air yang jernih, dan rasa yang alami sehingga dapat melekatkan merek Yeh Buleleng di pikiran konsumen. PT Tirta Mumbul Jaya Abadi juga memberikan harga yang lebih murah dari para pesaingnya. Dilihat dari sisi promosi, PT Tirta Mumbul Jaya Abadi selama ini selalu berusaha mempergunakan media periklanan baik cetak maupun elektronik dan sebagai sponsorship event-event keolahragaan untuk mengenalkan air minum kemasan Yeh Buleleng kepada konsumen. Sedangkan ditinjau dari saluran distribusi, PT Tirta Mumbul Jaya Abadi selama ini memiliki armada transportasi yang cukup memadai mulai dari kendaraan truk box, mobil pick up dan sepeda motor sehingga arus pendistribusian barang dengan sistem dropping menjadi sangat lancar. Keempat bauran pemasaran tersebut telah senantiasa diterapkan oleh PT Tirta Mumbul Jaya Abadi dalam memasarkan air minum kemasan Yeh Buleleng, namun melihat market share air minum kemasan Yeh Buleleng yang masih kalah dengan air minum kemasan Aqua menjadikan pertanyaan besar bagi manajemen PT Tirta Mumbul Jaya Abadi sampai sejauh mana pengaruh masing-masing bauran pemasaran tersebut terhadap keputusan konsumen dalam membeli air minum kemasan Yeh Buleleng. Berdasarkan paparan kondisi persaingan bisnis air minum kemasan Yeh Buleleng dan penerapan bauran pemasaran oleh PT Tirta Mumbul Jaya Abadi, maka dipandang perlu untuk meneliti pengaruh bauran pemasaran terhadap keputusan konsumen dalam membeli air minum kemasan Yeh Buleleng (studi kasus di Kabupaten Buleleng).

\section{Metode}

Secara umum jenis penelitian ini adalah penelitian deskriptif yang bertujuan membuat gambaran secara sistematis data faktual dan akurat mengenai fakta-fakta serta hubungan antar fenomena pengaruh bauran pemasaran terhadap keputusan konsumen dalam membeli air minum kemasan Yeh Buleleng (studi kasus di Kabupaten Buleleng). Dikarenakan sumber data berupa jawaban kuesioner yang berupa pilihan yang diubah kedalam angka-angka, maka secara khusus jenis penelitian ini adalah penelitian deskriptif kualitatif yang dikuantitatifkan. Menurut Arikunto (2002:213), penelitian deskrptif kualitatif yang dikuantitatifkan dilakukan dengan mengumpulkan data berupa jawaban pada kuesioner 
yang kemudian diubah ke bobot angka pada skala Likert dalam penelitian korelasional, komparatif, atau eksperimen untuk selanjutnya diolah dengan rumus-rumus statistik. Pengumpulan data sangat diperlukan agar tidak terjadi kesalahan dalam pengambilan data dari responden sehingga kesimpulan akhir dalam penelitian memang benar mencerminkan situasi dan kondisi dilapangan. Tahap awal dalam pengumpulan data diperlukan penetapan populasi dan sampel penelitian yang tepat.

Populasi dalam penelitian ini berupa konsumen yang pernah membeli air minum kemasan Yeh Buleleng. Dikarenakan jumlah pembeli air minum kemasan Yeh Buleleng sangat banyak dan tidak diketahui jumlahnya secara pasti, maka dalam penelitian ini digunakan populasi Unlimited (tidak terbatas). Penentuan besaran ukuran sampel, akan digunakan model yang dikemukan oleh Ferdinand. Penentuan sampel ini menggunakan lima sampai sepuluh kali jumlah indikator pada masing-masing variabel yang ditentukan (Ferdinand, 2002 : 48). Pada penelitian ini, jumlah indikatornya adalah 25, sehingga sampel yang layak diambil adalah sebanyak 125 sampai 250 orang. Dikarenakan adanya keterbatasan waktu, tenaga dan biaya, maka jumlah sampel yang dianggap layak diambil dalam penelitian ini adalah 170 orang (nilai tengah antara 125 dan 250). Teknik dalam penentuan anggota sampel, digunakan dua teknik secara berurutan yaitu: cluster sampling dan proportionate stratified random sampling.

Penggunaan cluster sampling dalam penelitian ini dikarenakan luasnya daerah Kabupaten Buleleng sebagai tempat penelitian. Melalui teknik cluster sampling, peneliti mendapatkan secara acak tiga Kecamatan sebagai tempat penelitian dari sembilan kecamatan yang terdapat di Kabupaten Buleleng. Pengambilan kecamatan secara acak dilakukan dengan mengundi kesembilan Kecamatan di Kabupaten Buleleng Buleleng. Ketiga kecamatan tersebut meliputi: Kecamatan Buleleng (mewakili daerah Kabupaten Buleleng bagian tengah), Kecamatan Sawan (mewakili daerah Kabupaten Buleleng bagian timur), dan Kecamatan Seririt (mewakili daerah Kabupaten Buleleng bagian barat). Sedangkan teknik Proportionate Stratified Random Sampling digunakan bila populasi mempunyai anggota/unsur yang tidak homogen dan berstrata secara proporsional. Dalam penelitian ini, anggota sampel akan dibedakan berdasarkan jumlah penduduk dan jenis pekerjaan pada masing-masing responden. Proporsi jumlah sampel yang akan diambil pada tiga kecamatan berdasarkan jumlah populasi yaitu 170 orang. Untuk lebih jelasnya, jumlah pengambilan sampel berdasarkan teknik Proportionate Stratified Random Sampling dapat dilihat pada Tabel 1.

\begin{tabular}{lccccc}
\multicolumn{1}{c}{\begin{tabular}{c} 
Tabel 1. Teknik Penentuan Anggota Sampel Air Minum Kemasan Yeh Buleleng \\
\cline { 1 - 4 } $\begin{array}{c}\text { Wilayah } \\
\text { (Kecamatan) }\end{array}$
\end{tabular}} & $\begin{array}{c}\text { PNS/ } \\
\text { TNI-Polri } \\
\text { (orang) }\end{array}$ & $\begin{array}{c}\text { Swasta } \\
\text { (orang) }\end{array}$ & $\begin{array}{c}\text { Petani/ } \\
\text { Nelayan } \\
\text { (orang) }\end{array}$ & $\begin{array}{c}\text { Lainnya } \\
\text { (orang) }\end{array}$ & \\
\hline 1. Buleleng & 18 & 45 & 13 & 9 & 85 \\
2. Sawan & 3 & 9 & 28 & 1 & 41 \\
3. Seririt & 1 & 15 & 25 & 3 & 44 \\
\hline \multicolumn{1}{c}{ Total } & 61 & 52 & 36 & 21 & 170 \\
\hline
\end{tabular}

Dalam proses penelitian ini, peneliti menggunakan metode pengumpulan data yaitu dokumentasi dan angket dengan instrumen penelitian berupa kuesioner. Penelitian ini menggunakan kuesioner yang memiliki format sebanyak 25 pernyataan tentang pengaruh bauran pemasaran terhadap keputusan konsumen dalam membeli Air Minum Kemasan Yeh Buleleng, dimana 25 pernyataan kuesioner tersebut akan mewakili 25 indikator dari bauran pemasaran dan keputusan pembelian. Untuk mengetahui pengaruh bauran pemasaran terhadap keputusan pembeliaan melalui kuesioner, maka digunakan skala Likert dengan degradasi nilai satu sampai dengan lima. Menurut Riduwan, (2007 : 16), skala Likert merupakan skala yang digunakan untuk mengukur sikap, pendapat dan persepsi seseorang atau sekelompok tentang kejadian atau gejala sosial. Kuesioner yang dipakai diuji validitas dan reliabilitasnya untuk mengetahui keakuratan kuesioner dalam mengukur indikator. Untuk 
mengetahui valid tidaknya item pernyataan dan reliabel tidaknya daftar pernyataan, dilakukan analisis validitas dan reliabilitas dengan bantuan software SPSS ver. 17.00.

Sebelum menguji hipotesis melalui model regresi, maka hipotesis akan diuji melalui uji asumsi klasik meliputi uji normalitas, uji multikolinearitas dan uji heteroskedastisitas. Metode analisis data yang digunakan dalam penelitian ini adalah analisis faktor regresi, dimana indikator setiap variabel bebas akan dianalisis terlebih dahulu menggunakan analisis faktor. Hasil daripada analisis faktor pada setiap indikator variabel bebas digunakan sebagai nilai yang menggambarkan variabel bebas (produk, harga, promosi dan saluran distribusi) untuk selanjutnya diregresikan terhadap variabel terikat (keputusan pembeliaan). Teknik analisis Faktor Regresi (Factor Analysis of Regression) dengan persamaan (Bernardo, 2003:125)

$$
Y=X \beta+€
$$

Keterangan:

$\mathrm{Y}=\mathrm{n}$-vector of responses

$X=n X p$ matrix of predictors

$\beta=p$-vector regression parameter

$€=\mathrm{n}$-vector error term

Dari rumusan diatas, tehnik pemecahan permasalahan secara berurutan menggunakan analisis faktor, principle component analisys (pca) dan terakhir regresi berganda. Regresi berganda digunakan untuk mengetahui pengaruh bauran pemasaran terhadap keputusan konsumen dalam membeli air minum kemasan Yeh Buleleng (studi kasus di Kabupaten Buleleng). Secara umum persamaan analisis regresi berganda dapat dirumuskan sebagai berikut:

$$
Y=B_{0}+B_{1} X_{1}+B_{2} X_{2}+B_{3} X_{3}+B_{4} X_{4}+e
$$

Keterangan:

$\mathrm{Y} \quad=$ Keputusan konsumen dalam membeli air minum kemasan Yeh Buleleng

$\mathrm{X}_{1} \quad=$ Produk

$\mathrm{X}_{2}=$ Harga

$\mathrm{X}_{3} \quad=$ Promosi

$\mathrm{X}_{4} \quad=$ Saluran distribusi

$\mathrm{B}_{0} \quad=$ Konstanta

$\mathrm{B}_{1} . . \mathrm{B}_{4}=$ Koefisien regresi $\mathrm{X}_{1}, \mathrm{X}_{2}, \mathrm{X}_{3}, \mathrm{X}_{4}$

$\mathrm{e} \quad=$ Variabel yang tidak diteliti

Pengaruh variabel independen terhadap variabel dependen diuji dengan tingkat kepercayaan 95 persen atau $\alpha=0,05$. Pengujian hipotesis dapat diuji secara serempak melalui uji $\mathrm{F}$ dan diuji secara parsial melalui uji t. Untuk menguji hipotesis secara serempak digunakan statistik F (Uji F). Menurut Sugiyono (2002:200), rumus yang digunakan untuk statistik F (Uji F) adalah:

$$
F-\text { hitung }=\frac{R^{2} / k}{\left(1-R^{2}\right) /(n-k-1)}
$$

Keterangan:

$\mathrm{R}^{2}=$ koefisien determinasi

$\mathrm{n}=$ jumlah data atau kasus

$\mathrm{k}=$ jumlah variabel independen

Untuk menguji hipotesis secara parsial digunakan statistik t (uji t). Menurut Sugiyono (2002:201), rumus yang digunakan untuk statistik $t$ ( uji t) adalah:

$$
\mathrm{t}=\frac{r_{p} \times \sqrt{n-2}}{\sqrt{1-r_{p}{ }^{2}}}
$$


Keterangan:

$r_{p}=$ koelasi parsial yang di temukan

$\mathrm{n}=$ jumlah sampel

$\mathrm{t}=\mathrm{t}$ hitung yang selanjutnya dilihat pada $\mathrm{t}$ tabel

Jika $t_{\text {hitung }} \leq t t_{\text {tabel }} \mathrm{H}_{0}$ diterima ( $\mathrm{H}_{1}$ ditolak), dan jika $\mathrm{t}_{\text {hitung }}>\mathrm{t}$ tabel $\mathrm{H}_{0}$ ditolak $\left(\mathrm{H}_{1}\right.$ diterima) pada $\alpha=0,05$.

\section{Hasil dan Pembahasan}

Uji normalitas dilakukan dengan menggunakan uji Kolmogorov Smirnov. Menurut Uyanto (2006:41) menyatakan, data dikatakan terdistribusi normal jika nilai signifikansi uji Kolmogorov Smirnov lebih besar dari 0,05. Berdasarkan pengujian dengan SPSS diperoleh hasil uji normalitas data adalah 0,149 sehingga dapat dikatan data terdistribusi normal karena nilai signifikansinya sudah diatas 0,05 . Untuk mendeteksi apakah model regresi mengalami multikolinieritas, dapat diperiksa menggunakan VIF. Kutner et.al (2004:264) menyatakan VIF merupakan singkatan dari Variance Inflation Factor. Nilai VIF > 5 berarti telah terjadi multikolinieritas yang serius di dalam model regresi. Hasil analisis multikolinearitas disajikan pada Tabel 2.

Tabel 2. Hasil Uji Multikolinearitas

\begin{tabular}{clcc}
\hline No & Variabel & $\begin{array}{c}\text { VIF (Variance } \\
\text { Inflation Factor) }\end{array}$ & Keterangan \\
\hline 1 & Produk & 3,055 & Tidak ada multikolinearitas \\
2 & Harga & 2,213 & Tidak ada multikolinearitas \\
3 & Lokasi & 1,902 & Tidak ada multikolinearitas \\
4 & Promosi & 2,912 & Tidak ada multikolinearitas \\
\hline
\end{tabular}

Dilihat dari uji heterokedasitas dapat diketahui, apabila probabilitas semua variabel bebas tidak ada yang signifikan atau lebih besar dari 0,05 berarti persamaan regresi tersebut tidak mengandung heterokedastisitas. Sebaliknya, jika probabilitas variabel bebas lebih kecil dari 0,05 berarti persamaan regresi mengandung heterokedastisitas. Hasil uji heterokedastisitas dapat dilihat pada Tabel 3.

Tabel 3. Hasil Uji Heterokedastisitas

\begin{tabular}{lllll}
\hline No & Variabel Bebas & Std. E & Sig & Keterangan \\
\hline 1 & Produk & 0,054 & 0,059 & Homokedastisitas \\
2 & Harga & 0,054 & 0,818 & Homokedastisitas \\
3 & Promosi & 0,061 & 0,087 & Homokedastisitas \\
4 & Saluran Distribusi & 0,070 & 0,783 & Homokedastisitas \\
\hline
\end{tabular}

Metode regresi berganda digunakan untuk menganalisis skor faktor dari masingmasing variabel yang terbentuk dalam analisis faktor sehingga diketahui kuat lemahnya hubungan, sifat dan besarnya pengaruh variabel produk, harga, lokasi dan saluran distribusi terhadap keputusan konsumen dalam membeli air minum kemasan Yeh Buleleng. Berdasarkan analisis regresi berganda dengan bantuan software SPSS ver 17.00, maka hasilnya dapat dilihat pada Tabel 4. 
Tabel 4. Hasil Regresi Berganda

\begin{tabular}{|c|c|c|c|c|}
\hline \multirow[t]{2}{*}{ Variabel Penelitian } & \multicolumn{2}{|c|}{ Unstandardized Coeffisiets } & \multirow{2}{*}{$\begin{array}{c}\text { Standardized } \\
\text { Coeffisients } \\
\text { Beta }\end{array}$} & \multirow[t]{2}{*}{ Sig } \\
\hline & $B$ & Std Error & & \\
\hline Produk & 0,203 & 0,083 & 0,236 & 0,015 \\
\hline Harga & 0,278 & 0,085 & 0,225 & 0,001 \\
\hline Promosi & 0,309 & 0,095 & 0,248 & 0,001 \\
\hline Saluran Distribusl & 0,317 & 0,106 & 0,286 & 0,003 \\
\hline $\begin{array}{l}\mathrm{R}=0,989 \\
R \text { Square }=0,978 \\
\text { Adjusted } R \text { Square }= \\
\mathrm{F}=1858,024 \\
\text { Sig. } \mathrm{Uji} \mathrm{F}=0,000\end{array}$ & & & & \\
\hline
\end{tabular}

Berdasarkan Tabel 4 maka dapat dibuat persamaan regresi tentang pengaruh variabel produk (X1), Harga (X2), Promosi (X3), dan saluran distribusi (X4) terhadap keputusan pembelian konsumen $(Y)$ seperti berikut ini:

$$
Y=0,203 X_{1}+0,278 X_{2}+0,309 X_{3}+0,317 X_{4}
$$

Persamaan garis regresi yang diperoleh dapat dijelaskan bahwa keempat variabel bauran pemasaran yaitu produk, harga, promosi, dan saluran distribusi memiliki pengaruh positif terhadap keputusan pembelian konsumen. Hal ini berarti semakin baik penilaian terhadap variabel produk, harga, promosi, dan saluran distribusi maka konsumen akan semakin sering memutuskan untuk membeli air minum kemasan Yeh Buleleng. Hasil perhitungan determinasinya diperoleh nilai $R^{2}$ sebesar 0,978 yang berarti 97,8 persen variasi keputusan pembelian konsumen dapat dijelaskan secara simultan oleh variabel produk, harga, promosi, dan saluran distribusi.

Pengujian empat variabel bauran pemasaran dilakukan dengan uji t. Secara khusus uji t digunakan untuk membuktikan hipotesis penelitian bahwa produk, harga, promosi dan saluran distribusi berpengaruh signifikan terhadap keputusan konsumen dalam membeli air minum kemasan Yeh Buleleng. Melalui analisis dengan program SPSS versi 17.00, maka besarnya nilai uji t (t hitung) dari masing-masing faktor bauran pemasaran disajikan pada Tabel 5.

Tabel 5. Hasil Uji t pada Regresi Berganda

\begin{tabular}{clccc}
\hline No & \multicolumn{1}{c}{ Faktor } & T hitung & Sig & Keterangan \\
\hline 1 & Produk & 2,499 & 0,015 & Signifikan \\
2 & Harga & 3,281 & 0,001 & Signifikan \\
3 & Promosi & 3,262 & 0,001 & Signifikan \\
4 & Saluran Distribusi & 3,000 & 0,003 & Signifikan \\
\hline
\end{tabular}

Berdasarkan Tabel 5 maka dapat diketahui semua variabel bauran pemasaran memiliki nilai signifikan sebagai berikut: produk $=0,015$, harga $=0,001$, promosi $=0,001$, dan saluran distribusi $=0,003$. Dengan penggunaan tingkat kesalahan lima persen maka secara parsial variabel produk, variabel harga, variabel promosi dan variabel saluran distribusi adalah signifikan berpengaruh terhadap keputusan konsumen dalam membeli air minum kemasan Yeh Buleleng.

Berdasarkan perhitungan SPSS maka dapat diketahui $F$ hitung sebesar 1858,024, sedangkan $\mathrm{F}$ tabel dapat diketahui dengan formulasi hipotesis sebagai berikut:

1. Merumuskan Formulasi Hipotesis

$\mathrm{H}_{0}=\mathrm{B}_{1}, \mathrm{~B}_{2}, \mathrm{~B}_{3}, \mathrm{~B}_{4}=0 \quad$ (bauran pemasaran yang terdiri atas produk, harga, promosi dan saluran distribusi secara serempak tidak ada pengaruh terhadap keputusan konsumen dalam membeli air minum kemasan Yeh Buleleng). 
$\mathrm{H}_{\mathrm{i}}=\mathrm{B}_{1}, \mathrm{~B}_{2}, \mathrm{~B}_{3}, \mathrm{~B}_{4} \neq 0$

(bauran pemasaran yang terdiri atas produk, harga, promosi dan saluran distribusi secara serempak berpengaruh positif dan signifikan terhadap keputusan konsumen dalam membeli

2. Menentukan Tingkat Kepercayaan air minum kemasan Yeh Buleleng).

Tingkat kepercayaan adalah 95 persen, $\alpha=0,05$, df $1=$ jumlah variabel $-1=(5-1)=4$, dan df $2=(n-k-1)=170-5-1=166$ sehingga nilai $F$ tabel $=2,41$

3. Merumuskan Kriteria Pengujian

Jika $F_{\text {hitung }}>F_{\text {tabel }}$ maka Ho ditolak

Jika $F_{\text {hitung }} \leq F_{\text {tabel }}$ maka Ho diterima

4. Menghitung nilai $F_{\text {hitung }}$

Hasil pengolahan data menggunakan program SPSS menghasilkan nilai $F_{\text {hitung }}$ sebesar 1858,024

5. Membuat gambar daerah penerimaan/penolakan Ho

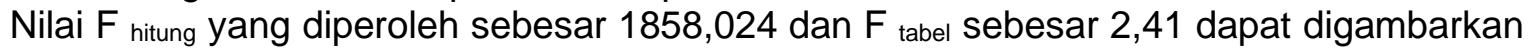
sebagai berikut.

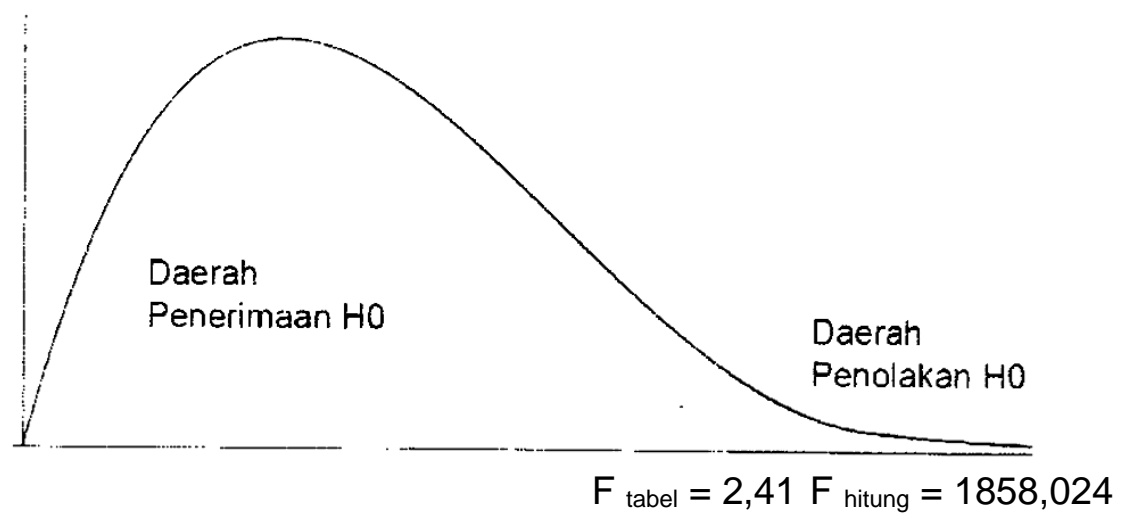

Gambar 2 Daerah Penerimaan dan Penolakan Ho untuk Uji F

6. Membuat Keputusan Uji Hipotesis

$\mathrm{F}$ hitung sebesar 1858,024 sedangkan $\mathrm{F}$ tabel 2,41 maka dengan demikian $\mathrm{F}$ hitung lebih besar dibandingkan $\mathrm{F}$ tabel. Kondisi ini menggambarkan Ho ditolak, Hi diterima dengan tingkat signifikansi 0,000 . Secara keseluruhan dapat dikatakan bahwa produk, harga, promosi dan saluran distribusi berpengaruh positif dan signifikan terhadap keputusan konsumen dalam membeli air minum kemasan Yeh Buleleng. Dengan demikian hipotesis dapat diterima dan teruji kebenarannya.

Pengukuran variabel yang berpengaruh dominan terhadap keputusan konsumen dalam membeli air minum kemasan Yeh Buleleng dapat dilakukan dengan melihat standardized coeficients beta tertinggi. Variabel bauran pemasaran yang memiliki nilai beta tertinggi merupakan variabel yang berpengaruh dominan terhadap keputusan konsumen dalam membeli air minum kemasan Yeh Buleleng. Adapun hasil standardized coeficients berdasarkan perhitungan analisis regresi berganda yang telah dilakukan seperti yang terangkum pada Tabel 6.

Tabel 6. Hasil Analisis Koefisien Beta Standardized

\begin{tabular}{|c|c|c|c|}
\hline No & Variabel & Beta Standardized & Peringkat \\
\hline 1 & Produk & 0,236 & III \\
\hline 2 & Harga & 0,225 & IV \\
\hline 3 & Promosi & 0,248 & II \\
\hline 4 & Saluran Distribusi & 0,286 & I \\
\hline
\end{tabular}

Ditinjau dari Tabel 6, maka dapat dijelaskan bahwa koefisien beta tertinggi adalah variabel saluran distribusi yaitu sebesar 0,286 berada pada peringkat pertama, kemudian 
variabel promosi pada peringkat kedua dengan koefisien beta 0,248 , disusul variabel produk dengan koefisien beta 0,236 dan peringkat terakhir diduduki oleh variabel harga dengan koefisien beta 0,225. Oleh karena itu dapat diketahui bahwa variabel yang paling berpengaruh dominan terhadap keputusan konsumen dalam membeli air minum kemasan Yeh Buleleng adalah saluran distribusi.

\section{Simpulan dan Saran}

Berdasarkan hasil analisis program SPSS, maka dapat disimpulkan bahwa bauran pemasaran berpengaruh terhadap keputusan konsumen dalam membeli air minum kemasan Yeh Buleleng (studi kasus di Kabupaten Buleleng) dengan perincian masing-masing bauran pemasaran sebagai berikut: 1. Produk berpengaruh positif dan signifikan terhadap keputusan konsumen dalam membeli air minum kemasan Yeh Buleleng di Kabupaten Buleleng, 2. Harga berpengaruh positif dan signifikan terhadap keputusan konsumen dalam membeli air minum kemasan Yeh Buleleng di Kabupaten Buleleng, 3. Promosi berpengaruh positif dan signifikan terhadap keputusan konsumen dalam membeli air minum kemasan Yeh Buleleng di Kabupaten Buleleng, 4. Saluran distribusi berpengaruh positif dan signifikan terhadap keputusan konsumen dalam membeli air minum kemasan Yeh Buleleng studi kasus di Kabupaten Buleleng, dan 5. Secara keseluruhan dapat dikatakan bahwa produk, harga, promosi dan saluran distribusi secara simultan berpengaruh positif dan signifikan terhadap keputusan konsumen dalam membeli air minum kemasan Yeh Buleleng di Kabupaten Buleleng. Bauran pemasaran yang dominan berpengaruh terhadap keputusan konsumen dalam membeli air minum kemasan Yeh Buleleng adalah saluran distribusi dengan nilai beta 0,286. Peringkat kedua diduduki oleh promosi dengan nilai beta 0,248. Peringkat ketiga diduduki oleh produk dengan nilai beta 0,236 dan peringkat keempat sekaligus yang memiliki pengaruh paling kecil adalah harga dengan nilai beta sebesar 0,225.

Adapun saran-saran yang dapat diberikan kepada PT Tirta Mumbul Jaya Abadi dalam memasarkan air minum kemasan Yeh Buleleng yaitu: 1. PT Tirta Mumbul Jaya Abadi diharapkan meningkatkan semua bauran pemasaran meliputi produk, harga, promosi dan saluran distribusi karena mempunyai pengaruh yang positif dan signifikan terhadap keputusan konsumen dalam membeli air minum kemasan Yeh Buleleng. Bauran pemasaran yang harus lebih diperhatikan secara seksama oleh PT Tirta Mumbul Jaya Abadi sehingga dapat lebih ditingkatkan adalah promosi, produk dan harga air minum kemasan Yeh Buleleng. Harga harus mendapatkan prioritas utama karena memiliki pengaruh paling kecil diantara bauran pemasaran lainnya terhadap keputusan konsumen dalam membeli air minum kemasan Yeh Buleleng di Kabupaten Buleleng, 2. Saluran distribusi diketahui lebih dominan berpengaruh terhadap keputusan konsumen dalam membeli air minum kemasan Yeh Buleleng. Oleh karena itu diharapkan PT Tirta Mumbul Jaya Abadi untuk dapat mempertahankan bahkan memperluas lagi daerah penjualannya sehingga dapat lebih dekat dan mudah diperoleh oleh konsumen. Hal ini dapat dilakukan dengan lebih mengekfektifkan penggunaan armada sepeda motor untuk menjangkau lokasi toko-toko penjual yang letak lokasinya berada ditengah-tengah pemukiman warga dan sulit dilalui oleh kendaraan roda empat. Kondisi tersebut sebaiknya diikuti juga dengan penambahan ekstension sambungan telepon dari saat ini satu line menjadi dua line untuk mempercepat komunikasi hubungan antara distributor, agen dan toko-toko dalam hal pemesanan air minum kemasan Yeh Buleleng sehingga jika terjadi kekurangan stok persediaan maka akan dengan cepat direspon oleh PT Tirta Mumbul Jaya Abadi. Hal ini penting agar air minum kemasan Yeh Buleleng cepat tersedia dan dijual lengkap dengan berbagai kemasannya, sehingga kebutuhan konsumen akan air minum kemasan Yeh Buleleng dapat dipenuhi. Manajemen PT. Tirta Mumbul Jaya Abadi juga diharapkan senantiasa mengkomunikasikan cara penyimpanan persediaan air minum kemasan Yeh Buleleng yang baik yaitu ditempat sejuk kepada distributor, agen, dan took-toko penjual air minum kemasan Yeh Buleleng agar kualitas air yang dijual dapat terus terjaga, 3. Promosi yang telah dilakukan saat ini oleh PT Tirta Mumbul Jaya Abadi sudah baik namun perlu lebih ditingkatkan lagi. Pihak manajemen PT Tirta Mumbul Jaya Abadi diharapkan membuat iklan pada surat kabar dan radio atau televisi lebih menarik dan atraktif dengan menggunakan bahasa yang mudah dicerna dan 
diinget serta menempatkan iklan pada halaman atau program yang membahas rubrik kesehatan maupun olah raga. Hal ini tidaklah berlebihan dikarenakan berdasarkan karakteristik responden air minum kemasan Yeh Buleleng yang lebih banyak berjenis kelamin laki-laki, yang tentunya sangat gemar beraktivitas dan senantiasa menjaga kesehatan tubuhnya. Selain itu pihak manajemen harus mulai berpikir menciptakan promosi yang edukatif, tidak hanya sebagai sponsorship di event olah raga tetapi juga sebagai sponsorship pada lomba-lomba pendidikan di Kabupaten Buleleng, sehingga nantinya pemberitaan tentang Air minum kemasan Yeh Buleleng tidak hanya dikenal sebagai air minum kemasan yang baik untuk kesehatan tetapi juga untuk kecerdasan otak. Promosi yang semakin tepat, tentu akan meningkatkan jumlah penjualan air minum kemasan Yeh Buleleng, 4. Produk air minum kemasan Yeh Buleleng yang diproduksi oleh PT Tirta Mumbul Jaya Abadi sudah cukup baik, kedepan diharapkan manajemen PT Tirta Mumbul Jaya Abadi memberikan tambahan dana kepada bagian produksi untuk membeli mesin ozonisasi tingkat dua sehingga dapat lebih meningkatkan daya tahan masa kadaluarsa lebih lama lagi. Hal ini dikarenakan masa kadaluarsa air minum kemasan Yeh Buleleng masih terbilang pendek yaitu hanya dapat bertahan delapan bulan dari masa produksi. Dengan pembelian mesin ozonisasi tingkat dua, diharapkan masa kadaluarsa air minum kemasan Yeh Buleleng dapat diperpanjang hingga satu tahun sehingga dapat disimpan dalam jangka waktu yang lama tanpa menurunkan kualitas seperti kejernihan dan kealamian air. Selain itu, PT Tirta Mumbul Jaya Abadi diharapkan memperhatikan kejelasan tulisan merek Yeh Buleleng pada setiap kemasan dengan penggunaan ukuran serta tulisan yang mudah dibaca dan menarik untuk dilihat. Hal ini dikarenakan sebagian besar konsumen air minum kemasan Yeh Buleleng berumur 40 tahun sampai dengan 49 tahun yang tentunya kemampuan mengingat dan pengelihatannya sudah mulai bekurang, sehingga dengan kejelasan merek, konsumen diharapkan semakin mudah mengingat untuk membeli air minum kemasan Yeh Buleleng, dan 5. Harga air minum kemasan Yeh Buleleng yang ditawarkan saat ini sudah cukup baik, namun untuk kedepan perlu dipertimbangkan kembali karena menyangkut image produk. PT Tirta mumbul jaya Abadi diharapkan dapat menetapkan harga yang kompetitif dengan para pesaing utama maupun pesaing sejenis dipasaran yaitu tidak terlalu mahal, sehingga memunculkan kesan bahwa air minum kemasan Yeh Buleleng sebagai air minum kemasan yang berkualitas namun harganya masih dapat dijangkau oleh segala lapisan masnyarakat. Selain itu, diharapkan PT Tirta Mumbul Jaya Abadi tidak hanya memberikan potongan harga pada pembelian jumlah tertentu saja (diskon kuantitas), melainkan juga pada waktuwaktu tertentu (diskon musiman) terutama saat hari raya besar keagamaan yang sarat akan kebutuhan air minum kemasan yang higienis sehingga konsumen tertarik untuk membeli air minum kemasan Yeh Buleleng. Pemberian potongan harga ini harus selalu mempertimbangkan juga biaya produksi sehingga nantinya program potongan harga yang diberikan PT Tirta Mumbul Jaya Abadi tidak melebihi besaran harga pokok produksi, sehingga keuntungan selalu dapat diperoleh.

\section{Daftar Pustaka}

Fauzan, Andi. 2010. Analisis Strategi Pemasaran Air Minum Beroksigen "Airox" Pada PT Tirta Alam Semesta. e-repository, Bogor. Institut Pertanian Bogor.

Faizah, Lazza, dan Indira Rachmawati. 2013. Pengaruh Bauran Pemasaran Terhadap Keputusan Pembelian Air Minum dalam Kemasan Merek Aqua (Studi Kasus di Wilayah Kuningan Barat Jakarta Selatan Periode Oktober 2012 - maret 2013). Erepository, Bandung. Universitas Telkom.

Foster, Bob. 2016. Impact of Brand Image on Purchasing Decision on Mineral Water Product "Amidis" (Case Study on Bintang Trading Company). American Research Journal of Humanities ang Social Science, Volume 16 no 11.

Dharmmesta BS, Handoko TH, 2008, Manajemen Pemasaran (Analisis Perilaku Konsumen), Yogyakarta: BPFE. 
Hand, Eddie William Jr. The Effect of Marketing Information on The Reduction of Perceived Risk in The Purchase of Innovative Products: A Multi Product Factorial Experiment. Dissertation Abstract International. A The Humanity and Social Sciences, Michigan University Microfilms International, a bell and Howell Company Volume 54, Number 9 March 1994.

Kotler P, Keller KL, 2008, Manajemen Pemasaran. Jakarta: PT Indeks.

Kotler P, Amstrong G, 2004, Principles of Marketing Ten Edition, New Jersey: Prentice Hall.

Mowen JC. And Minor M, 2002, Perilaku Konsumen Jilid 1 Edisi Kelima. Jakarta: Penerbit Erlangga.

Schiffman L and Kanuk LL, 2007, Perilaku Konsumen. Jakarta: PT Indeks.

Suryani T, 2008, Perilaku Konsumen (Implikasi pada Strategi Pemasaran). Yogyakarta: Graha IImu.

Siringgoringo. Peran Bauran Pemasaran Terhadap Perilaku Pembelian Konsumen.. Fakultas Ekonomi, Universitas Gunadarma Depok. 125 jurnal ekonomi \& bisnis no. 3, Jilid 9, Tahun 2004 